
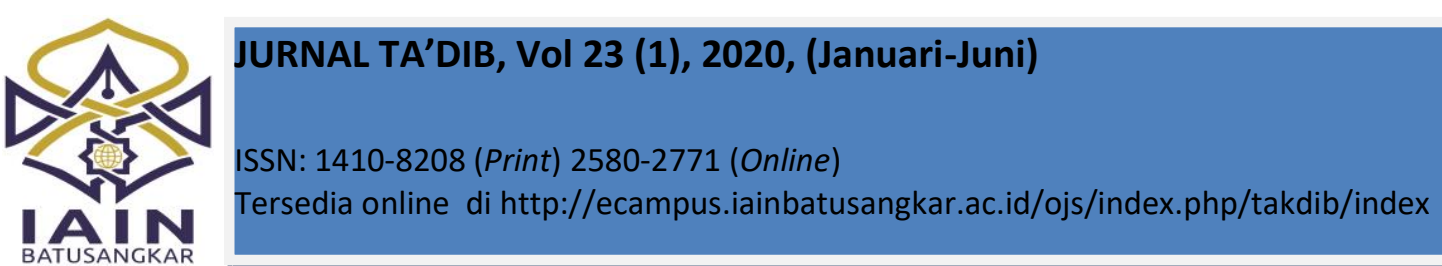

\title{
Pengaruh Model Problem Based Learning terhadap Kemampuan Literasi Sains Siswa SMA
}

\section{Rina Widiana}

STKIP PGRI Sumatera Barat, Indonesia E-mail:rinaroesdi68@gmail.com

\section{Ade Dewi Maharani*)}

STKIP PGRI Sumatera Barat, Indonesia E-mail:adedewimaharani@gmail.com

\section{Rowdoh}

STKIP PGRI Sumatera Barat, Indonesia E-mail:Rowdoh03@gmail.com

*) Corresponding Author

\begin{abstract}
Previously, the literacy skill of students class XI at SMAN 1 Lembah Melintang Pasaman Barat Regency was still low. The students only memorized concepts and theories so that they were not able to implement the concepts in their life. The research aimed at investigating the effect of the application of the Problem Based Learning on students' literacy skill. This research have been used Randomized Control Group Posttest Only Design. The sample of this research was high school students in class XI taken using simple random sampling. The data were analyzed with Mann Whitney test. The result shows the increase of the students' average literacy skill after being taught with Problem Based Learning in the affective, cognitive, and psychomotor domains. It can be concluded that the Problem Based Learning Model is effective on the students' scientific literacy skill in class XI of SMAN 1 Lembah Melintang Pasaman Barat.
\end{abstract}

\section{$\mathrm{M}^{\mathrm{prpD}}$} pembelajaran biologi. Sesuai pendapat Kemendikbud, (2019) "pembelajaran biologi yaitu pembelajaran yang menuntut keterlibatan aktif siswa dalam kerja ilmiah/inkuiri berkaitan dengan gejala alam, objek dan permasalahan yang terjadi dalam kehidupan sehari-hari”. Proses pembelajaran akan membuat terjadinya hubungan antara guru dengan siswa, dimana guru akan berperan dalam mendidik siswa baik itu dalam pengetahuannya maupun sikapnya. Guru akan membuat siswa termotivasi dengan menciptakan suasana kondusif dalam pembelajaran, sehingga guru akan menetapkan metode, model, maupun strategi pembelajaran yang digunakannya.

Dalam mengantarkan siswa menghadapi segala rintangan maupun tantangan dalam kehidupannya maka diperlukan arahan dalam proses pembelajaran melalui pembentukan kompetensi yang harus dikuasai seorang siswa, karena itu belajar tidak saja mendorong peserta didik untuk menguasai beberapa materi pembelajaran tapi bagaimana caranya siswa mempunyai beberapa kompetensi dalam menghadapi rintangan sesuai perubahan pola pikir dalam lingkungan masyarakat (Jufri, 2013).

Berdasarkan hasil observasi di SMAN 1 Lembah Melintang Kabupaten Pasaman Barat pada bulan Agustus-Oktober 2018, didapatkan bahwa guru lebih sering menggunakan metode ceramah dibanding motode lain, seperti metode diskusi yang lebih sesuai dengan materi yang diajarkan, sehingga guru cenderung sebagai pusat penyampai informasi dan siswa kurang dilibatkan dalam proses pembelajaran.

Kenyataannya dalam proses pembelajaran, siswa menghafal konsep dan teori saja serta kurang mampu menggunakan konsep yang dimiliki atau bisa dikatakan 
kemampuan literasi siswa belum terbentuk. Hal ini dibuktikan pada tahap apersepsi, hanya 35,6 \% siswa yang mampu menjawab fenomena alam dan pemecahan masalah yang terjadi sehari-hari yang diberikan guru dengan menggunakan konsep sains. Salah satu penyebabnya adalah belum mampunya siswa mengaitkan dan mengaplikasikan antara konsep yang dipelajari dengan situasi nyata pada lingkungannya, sehingga konsep pembelajaran biologi belum tercapai dan belum bisa melatih bernalar secara sains melalui literasi sains. Hasil penelitian Utami, Suciati, \& Prayitno (2015)" menunjukkan rendahnya kemampuan siswa dalam memberikan jawaban pertanyaan menggunakan konsep-konsep sains dalam pemecahan masalah mengindikasikan bahwa kemampuan literasi sains siswa rendah". Siswa dapat dikatakan memiliki kemampuan sains, jika mampu mengimplementasikan konsep, keterampilan dan nilai-nilai sains dalam membuat keputusan yang berhubungan dengan lingkungan dan kehidupannya sehari-hari.

Kelemahan dan dampak dari proses pembelajaran yang berlangsung di SMAN 1 Lembah Melintang ditunjukkan oleh $60 \%$ siswa kelas XI pada tahun pelajaran 2017/2018 memiliki nilai kurang dari KKM yang ditetapkan pada materi sistem koordinasi, yaitu 70. Materi sistem koordinasi termasuk materi yang sulit dipahami siswa2 dikarenakan materinya banyak dan membutuhkan pemahaman dan pengaplikasiannya dalam kehidupan seharihari.

Hasil wawancara dengan guru biologi pada tanggal 25 Januari 2019 mengenai soal yang digunakan dalam mengevaluasi ketercapaian hasil belajar siswa pada ulangan harian, didapatkan bahwa soal yang digunakan hanya menuntut pemahaman dan pengetahuan saja, sehingga belum sepenuhnya mampu menstimulasi ketertarikan siswa terhadap sains.
Berdasarkan hasil wawancara ini, maka dapat dilihat bahwa belum terbentuknya kemampuan literasi sains siswa kelas XI IPA SMAN 1 Lembah Melintang, selain belum ada penerapan model pembelajaran, juga disebabkan oleh soal ulangan harian yang digunakan belum menstimulasi pembentukan kemampuan literasi sains siswa. Berdasarkan permasalahan ini, Khairat (2017) menjelaskan bahwa guru dituntut untuk mampu menerapkan berbagai strategi pembelajaran agar hasil belajar siswa mencapai Kriteria Ketuntasan Minimal (KKM). Salah satu model pembelajaran yang dapat meningkatkan peguasaan materi dan pembentukan kemampuan literasi sains siswa, yaitu model Problem Based Learning (PBL). Hasil penelitian Rizkita, Suwono dan Susilo (2016), pada penggunaan strategi Problem Based Learning, terdapat peningkatan kemampuan literasi sains dengan menekankan kemampuan problem solving.

Model pembelajaran PBL memfokuskan pada permasalahan dan pertanyaan sehingga mampu membuat siswa menyelesaikan permasalahan dengan menggunakan konsep dan prinsip yang sesuai dan tidak jauh dengan literasi sains yang membantu siswa dalam menyelesaikan masalah. Pengukuran literasi sains siswa dengan penggunaan model perlu ditunjang dengan tes berbasis literasi. Sesuai dengan penelitian yang telah dilakukan Giriyanti (2017) "proses dari tahapan model berbasis masalah yang dilalui siswa dapat membuat terpenuhinya indikator yang digunakan dalam literasi sains siswa. Tahapan proses belajar dari model berbasis masalah yang digunakan dapat meningkatkan kemampuan literasi sains siswa, salah satunya pada aspek kompetensi".

Berdasarkan permasalahan di atas, maka dilakukan penelitian dengan tujuan melihat pengaruh model Problem Based Learning (PBL) terhadap kemampuan literasi sains 
siswa kelas XI SMA pada materi sistem koordinasi.

\section{METODE PENELITIAN}

Penelitian ini dirancang dengan Randomized control grup postes only design. Sampel adalah siswa kelas XI IPA SMAN 1 Lembah Melintang Tahun Pelajaran 2018/2019. Sampel diambil dengan teknik simple random sampling. Kelas perlakuan ditetapkan dengan cara pengundian.

Kemampuan literasi diukur pada ketiga ranah hasil belajar. Ranah kognitif menggunakan tes berbasis literasi yang berbentuk soal pilihan ganda, ranah afektif menggunakan angket penilaian diri dan teman sebaya, terakhir ranah psikomotor diukur dari laporan diskusi dan laporan analisis. Data dianalisis menggunakan uji perbedaan dua nilai rata-rata.

\section{HASIL DAN PEMBAHASAN \\ Hasil \\ Kemampuan Literasi}

Kemampuan literasi sains siswa pada setiap ranah disajikan pada Tabel 1.

Tabel 1. Rata-rata kemampuan literasi sains siswa pada ketiga ranah

\begin{tabular}{|c|c|c|c|c|c|c|}
\hline \multirow[t]{2}{*}{ Variabel } & \multicolumn{2}{|c|}{ Afektif } & \multicolumn{2}{|c|}{ Kognitif } & \multicolumn{2}{|c|}{ Psikomotor } \\
\hline & Eksperimen & Kontrol & Eksperimen & Kontrol & Eksperimen & Kontrol \\
\hline Rata-rata & 96,5 & 91,2 & 71,14 & 62,67 & 85,34 & 63,64 \\
\hline \multirow[t]{2}{*}{ Normalitas } & $\mathrm{LO}>\mathrm{Lt}$ & $\mathrm{LO}>\mathrm{Lt}$ & $\mathrm{LO}<\mathrm{Lt}$ & $\mathrm{L} 0<\mathrm{Lt}$ & $\mathrm{LO}>\mathrm{Lt}$ & $\mathrm{LO}>\mathrm{Lt}$ \\
\hline & $0,74>0,149$ & $0,70>0,149$ & $0,10<0,149$ & $0,15<0,151$ & $0,74>0,149$ & $0,63>0,149$ \\
\hline \multirow[t]{2}{*}{ Homogenitas } & \multicolumn{2}{|l|}{$\mathrm{Fh}<\mathrm{Ft}$} & \multicolumn{2}{|l|}{$\mathrm{Fh}<\mathrm{Ft}$} & \multicolumn{2}{|l|}{$\mathrm{Fh}<\mathrm{Ft}$} \\
\hline & \multicolumn{2}{|l|}{$1,15<1,82$} & \multicolumn{2}{|l|}{$0,69<1,82$} & \multicolumn{2}{|l|}{$0,02<1,82$} \\
\hline \multirow[t]{2}{*}{ Hipotesis } & \multicolumn{2}{|l|}{$\mathrm{Zh}<\mathrm{Zt}$} & \multicolumn{2}{|l|}{$\mathrm{Th}<\mathrm{Tt}$} & \multicolumn{2}{|l|}{$\mathrm{Zh}<\mathrm{Zt}$} \\
\hline & \multicolumn{2}{|l|}{$-1,65<0,05$} & \multicolumn{2}{|l|}{$4,43<1,668$} & \multicolumn{2}{|l|}{$-2,68<0,003$} \\
\hline Keterangan & \multicolumn{2}{|l|}{ H1 diterima } & \multicolumn{2}{|l|}{ H1 diterima } & \multicolumn{2}{|l|}{ H1 diterima } \\
\hline
\end{tabular}

Dari Tabel 1 terlihat bahwa model Problem Based Learning (PBL) berpengaruh terhadap kemampuan literasi sains siswa pada ketiga ranah penilaian. Rata-rata nilai kemampuan literasi sains siswa kelas eksperimen lebih tinggi dari kelas kontrol pada setiap ranah penilaian.
Pengaruh Model Problem Based Learning terhadap Kemampuan Literasi Sains Ketiga Ranah Penilaian Afektif

Rata-rata kemampuan literasi sains pada ranah afektif kelas ekperimen lebih tinggi dari kelas kontrol. Sikap tanggung jawab terhadap sumberdaya dan lingkungan merupakan indikator sikap literasi sains yang menonjol. Kemampuan literasi sains pada ranah afektif disajikan pada Gambar 1 . 


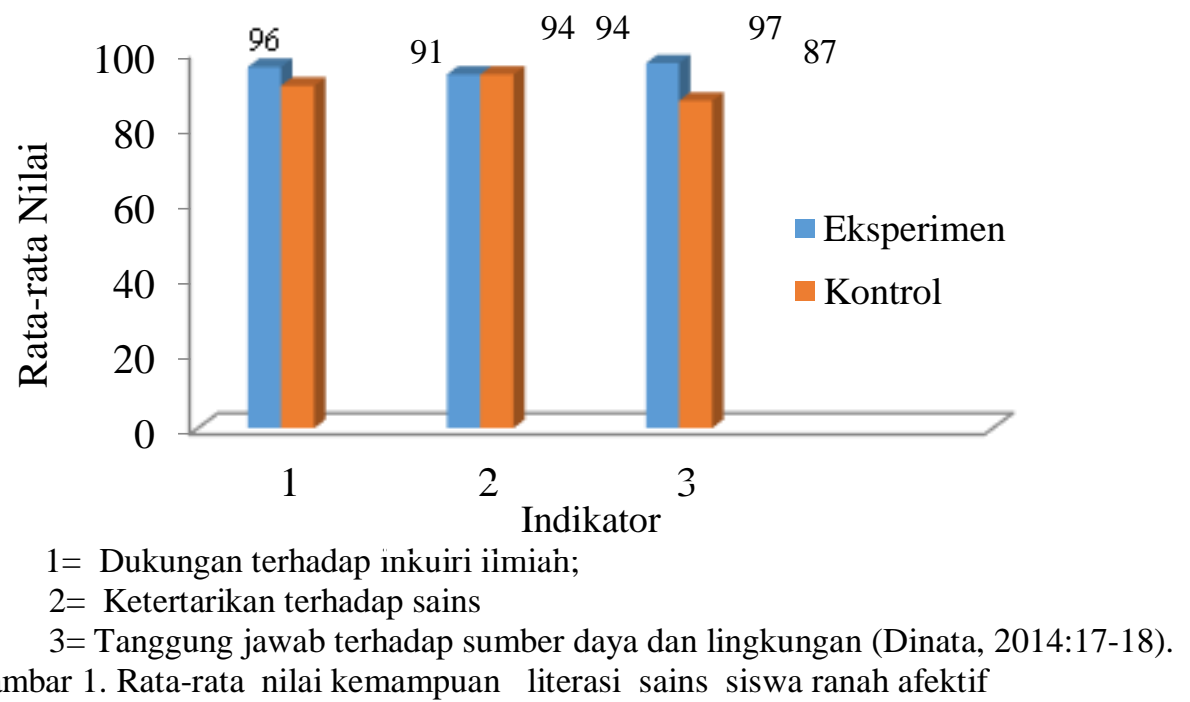

Gambar 1 menggambarkan model penilaian yaitu kemampuan menjelaskan pembelajaran PBL mampu membentuk sikap fenomena secara saintifik, kemampuan literasi sains siswa. Indikator yang menonjol mendesain dan mengevaluasi penyelidikan adalah tanggung jawab terhadap sumber daya secara saintifik dan kemampuan lingkungan sedangkan indikator paling menginterpretasikan data dan fakta secara rendah yaitu ketertarikan terhadap sains. saintifik. Hasil kemampuan literasi sains Kognitif

Kemampuan literasi sains siswa pada ranah kognitif diukur dengan tiga indikator pada ranah kognitif disajikan pada Gambar 2.

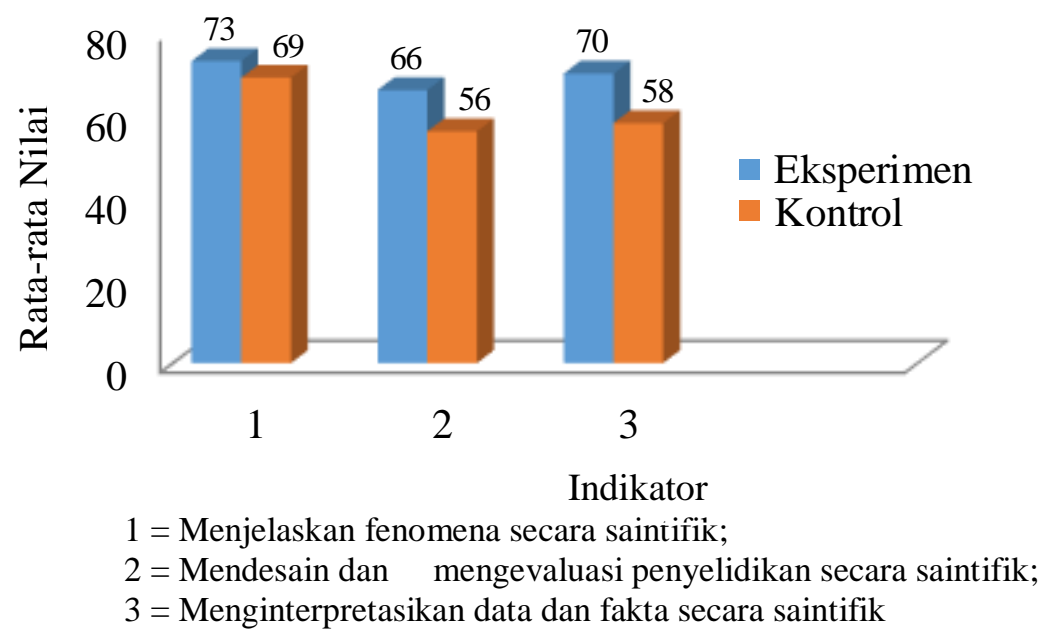

(Abidin, 2017:245).

Gambar 2. Rata-rata nilai kemampuan literasi sains siswa ranah kognitif

Dari Gambar 2. dapat dilihat nilai paling rendah yaitu mendesain dan kemampuan literasi sains kelas eksperimen lebih tinggi dari kelas kontrol. Kemampuan yang paling menonjol adalah menjelaskan mengevaluasi penyelidikan secara saintifik. Psikomotor

Hasil kemampuan literasi sains ranah fenomena secara saintifik dan indikator psikomotor dengan aspek isi laporan pada 
Gambar 3a dan kelengkapan umum laporan disajikan pada Gambar 3b:

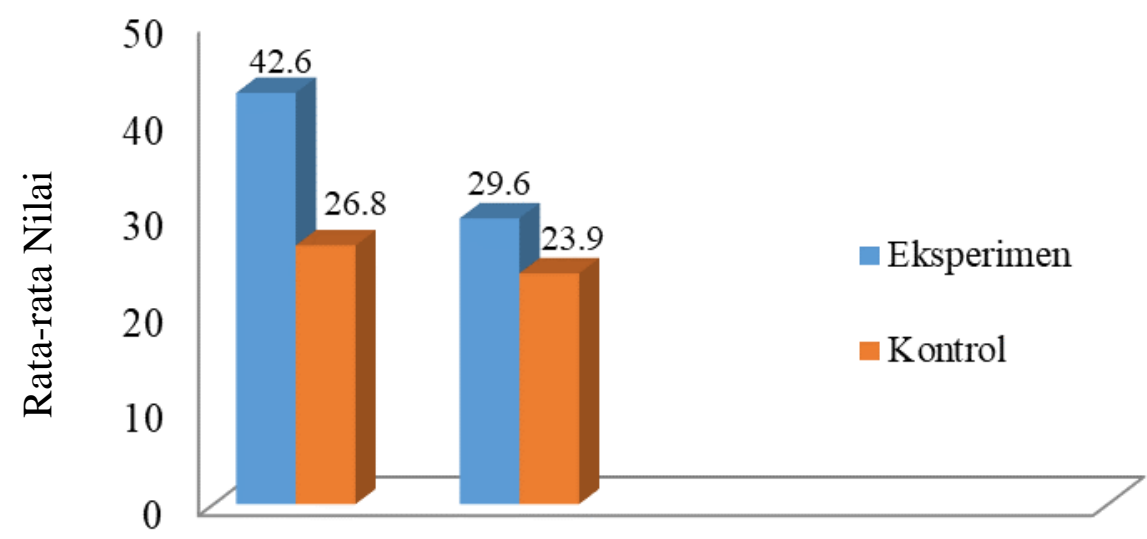

Gambar 3a. Rata nilai siswa pada ranah psikomotor (laporan diskusi)

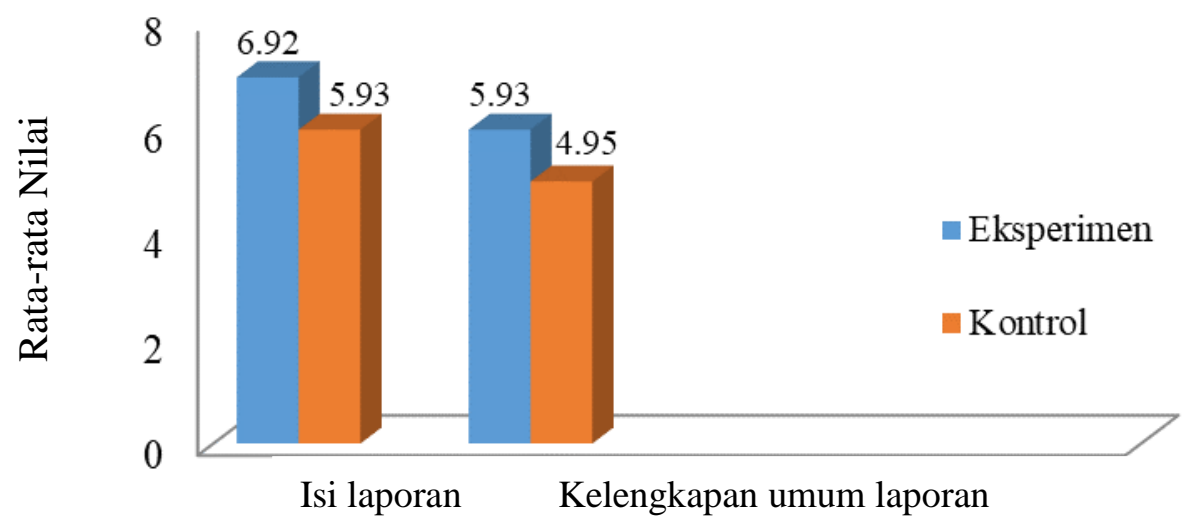

Gambr 3b. Rata nilai siswa pada ranah psikomotor (laporan analisis)

Dari Gambar 3a dan 3b dapat dilihat bahwa rata-rata nilai kemampuan literasi sains kelas eksperimen lebih tinggi dari kelas kontrol. Kemampuan yang paling menonjol adalah aspek isi laporan serta yang terendah aspek kelengkapan umum laporan.

\section{Pembahasan}

\section{Kemampuan Literasi}

Hasil penelitian menyatakan penerapan PBL berpengaruh terhadap kemampuan literasi sains siswa pada ketiga ranah hasil belajar. Tingginya kemampuan literasi sains disebabkan karena model yang diterapkan menstimulus siswa aktif dan kritis dalam mendapatkan solusi dari permasalahan.
Model PBL menuntut siswa membaca untuk mendapatkan solusi, sehingga tanpa disadari siswa terlatih dalam menyelesaikan masalah yang selanjutnya secara tidak langsung membentuk kemampuan literasi sains. Pembelajaran dengan model PBL membantu siswa menjadi pembelajar mandiri (Arends, 2012).

Tingginya kemampuan literasi sains siswa kelas ekperimen disebabkan karena proses pembelajaran menerapkan model pembelajaran PBL dan tahapannya menuntut siswa mencari sendiri mulai dari perumusan masalah, pemecahan masalah dan mengumpulkan data untuk pemecahan 
masalah dan membuat kesimpulan. Menurut penelitian Maurer \& Neuhold (2012), masalah yang disajikan dapat merangsang siswa untuk mengidentifikasi berbagai macam pertanyaan yang dapat diajukan sebagai rumusan masalah, sehingga siswa dapat mengenali pertanyaan-pertanyaan yang mungkin untuk diteruskan sebagai penyelidikan secara ilmiah. Sehingga dengan sendirinya budaya membaca siswa akan tumbuh dan kemampuan literasinya akan terbentuk dengan baik. Hal tersebut dilihat dari kemampuan siswa dalam mendapatkan ilmu baru, serta mengambil simpulan. Sesuai dengan konsep literasi menurut OECD (2016) dalam Kemendikbud, (2017) "literasi sains diartikan sebagai pengetahuan dan kecakapan ilmiah untuk mampu mengidentifikasi pertanyaan, memperoleh pengetahuan baru, menjelaskan fenomena ilmiah, serta mengambil simpulan berdasarkan fakta, memahami karakteristik sains, kesadaran bagaimana sains dan teknologi membentuk lingkungan alam, intelektual, dan budaya, serta kemampuan untuk terlibat dan peduli terhadap isu-isu yang terkait sains".

Tingginya literasi siswa kelas eksperimen juga didukung oleh bahan ajar yang digunakan, yaitu Lembar Kerja Peserta Didik. LKPD yang digunakan telah disesuaikan dengan model PBL yang digunakan dalam proses pembelajaran.

\section{Pengaruh Model Pembelajran PBL Terhadap Kemampuan Literasi Sains Ketiga Ranah Hasil Belajar Afektif}

Tingginya nilai kemampuan literasi pada ranah afektif dengan menggunakan tiga indikator sikap literasi sains kelas eksperimen disebabkan karena tahapan PBL mengharuskan siswa banyak membaca. Proses membaca ini secara tidak langsung telah membangkitkan rasa ingin tahu siswa pada materi. Sesuai pendapat Rubba (1993) dalam Dinata (2014) "karakteristik seseorang memiliki literasi sains adalah bersikap positif, adanya pengetahuan, dan mampu menerapkan sains".
Pertama; aspek inkuiri ilmiah, tingginya kemampuan literasi sains kelas eksperimen disebabkan tahapan model PBL yang digunakan sudah membangun pengetahuan peserta didik. Hal ini dilihat dalam menyelesaikan semua tahap PBL, dimana semua siswa terlihat aktif membaca buku sumber. Sesuai pendapat Sanjaya (2014) "kegiatan penyelidikan akan mengembangkan kecakapan siswa untuk mengumpulkan dan memilah data kemudian menyajikan suatu hasil yang mudah dipahami sehingga dapat menumbuhkan sikap literasi sains siswa".

Kedua; kemampuan literasi sains pada aspek ketertarikan terhadap sains kelas eksperimen dan kelas kontrol ditemukan sama tinggi. Hal ini dikarenakan model PBL (kelas eksperimen) dan pendekatan saintifik (kelas kontrol) sama-sama melatih siswa mengalami pemecahan masalah secara mandiri maupun bersama dengan menggunakan metode ilmiah. Sesuai pendapat Akcay (2010) dalam Dinata (2014:17) "sikap terhadap sains adalah perasaan, keyakinan dan nilai-nilai serta dampaknya bagi masyarakat".

Ketiga; aspek tanggung jawab terhadap sumberdaya dan lingkungan, tingginya nilai kemampuan literasi sains kelas ekperimen disebabkan semua tahapan model PBL yang digunakan telah menuntut siswa untuk banyak membaca untuk merumuskan masalah, memecahkan masalah dan merumuskan kesimpulan, baik secara sendiri serta semua tahap diselesaikan secara berurutan. Hal ini dengan sendirinya telah menumbuhkan rasa tanggung jawab terhadap tugas yang diberikan. Sejalan dengan pendapat Toharuddin (2011) bahwa "kemampuan seseorang untuk memahami sains, mengkomunikasikan sains, serta menerapkan sains untuk memecahkan masalah sehingga dapat menumbuhkan sikap terhadap diri dan lingkungan serta dalam mengambil keputusan".

\section{Kognitif}

Tingginya kemampuan literasi sains ranah kognitif pada ketiga indikator literasi disebabkan karena adanya proses 
pembelajaran menggunakan model PBL dan pengaruh tingkat literasi siswa dalam memahami materi, karena siswa yang benarbenar memiliki literasi yang tinggi akan mempengaruhi hasil kognitif siswa.

Pertama; aspek menjelaskan fenomena secara saintitfik, tingginya kemampuan literasi pada kelas eksperimen disebabkan karena tahapan Model PBL mampu meningkatkan pemahaman siswa dengan membaca, sehingga dengan sendirinya telah menumbuhkan kemampuan literasi sains siswa, dimana penguasaan kompetensi ini dapat dilihat pada proses belajar kelompok, siswa aktif menyampaikan ide-ide atau solusi yang memungkinkan untuk proses pemecahan masalah. Sesuai pendapat Abidin (2017) bahwa "menjelaskan fenomena diperlukan lebih untuk mengingat serta menggunakan teori tentang peran untuk membuktikan pengetahuan yang didapatkan oleh ilmu pengetahuan".

Kedua; aspek mendesain dan mengevaluasi penyelidikan saintifik, tingginya kemampuan literasi sains kelas eksperimen disebabkan karena penerapan Model PBL yang digunakan pada proses belajar dapat membuat siswa belajar cara merumuskan masalah dari permasalahan yang telah diberikan melalui LKPD. Permasalahan yang dirumuskan oleh siswa merupakan permasalahan yang ditemukan di lingkungan siswa dalam kehidupannya, sehingga siswa bisa mengaitkan upaya penyelesaian masalah dengan dunia nyata. Melalui permasalahan yang dihadapi, sehingga siswa mampu berfikir kritis, berkomunikasi, serta evaluatif. Sesuai dengan pendapat Abidin (2017:152) menyatakan "dalam kompetensi mendesain dan mengevaluasi penyelidikan saintifik mencakup kemampuan siswa dalam hal berkolabaorasi, berfikir kritis, dan evaluatif serta siswa harus memahami konsep pelaporan dan diseminasi hasil penyelidikan".

Ketiga; aspek menginterpretasikan data dan fakta secara saintifik, tingginya kemampuan literasi sains pada kelas ekperimen disebabkan karena Model PBL yang digunakan dalam proses pembelajaran. Solusi dari hasil merumuskan masalah dapat mengembangkan aspek literasi sains berupa menggunakan bukti ilmiah. Bukti-bukti yang telah dicari dari beberapa sumber yang digunakan untuk memecahkan permasalahan kemudian akan diinterpretasikan oleh siswa melalui kegiatan diskusi kelas, dimana siswa akan menyampaikan pendapat dengan dukungan bukti-bukti ilmiah yang telah mereka temukan. Sejalan dengan pernyataan Abidin (2017) "interpretasi data merupakan aktivitas dalam proses penelitian untuk mengingat dan menggunakan teori, ide, dan informasi".

\section{Psikomotor}

Penilaian psikomotor merupakan tahap terakhir yang dilakukan untuk mengimplementasikan hasil dari aspek afektif dan kognitif siswa. Penyebab kelas eksperimen lebih tinggi karena siswa sudah melalui tahapan Model Pembelajaran PBL yang mengharuskan banyak membaca dan menggunakan metode ilmiah, sehingga dapat melatih penulisan siswa pada laporan diskusi maupun laporan analisis. Sesuai pernyataan Kunandar, (2013:100) "sikap dilihat dari cara belajar seseorang, orang yang berminat belajar akan mendapatkan hasil yang optimal dan begitu sebaliknya".

\section{KESIMPULAN DAN REKOMENDASI}

Penerapan Model Pembelajaran

Problem Based Learning dapat meningkatkan kemampuan literasi sains siswa kelas XI di SMAN 1 Lembah Melintang Kabupaten Pasaman Barat pada ranah afektif, kognitif, dan psikomotor.

Berdasarkan hasil penelitian yang didapat, maka disarankan penelitian selanjutnya untuk menerapkan Model Pembelajaran Problem Based Learning dalam membentuk kemampuan literasi sains siswa pada materi dan sekolah lain serta dalam penerapan model pembelajatran PBL guru perlu mendisiplinkan penggunaan waktu, dan meningkatkan intensitas pemberian motivasi pada siswa agar lebih aktif bertanya dan mengeluarkan pendapat. 


\section{REFERENSI}

Abidin, Y. (2017). Pembelajaran Literasi: Strategi Meningkatkan Kemampuan Literasi Matematika, Sains, Membaca, dan Menulis. Jakarta: Bumi Aksara.

Akcay, H. e. al. (2010). change in student beliefs about attitudes toward science in grades 6-9.

Dinata, A. N. (2014). Pengaruh Field Trip Terhadap Kemampuan Literasi Sains dan Sikap Sains Siswa SMA Pada Materi Ekosistem, 17-18.

Djohar. (1987). Peningkatan proses belajar sains melalui pemanfaatan sumber belajar. yogyakarta: Ikip yogyakarta.

Giriyanti, P. (2017). Pengaruh Model Pembelajaran Berbasis Masalah Terhadap Kemampuan Literasi Sains Siswa Pada Materi Ekosistem Kelas X SMA, 5.
Jufri, W. (2013). Belajar dan pembelajaran sains. Bandung: Reka Cipta.

Kemendikbud. (2017). Materi Pendukung Literasi Sains. Jakarta: Kemendikbud.

Khairat, A. (2017). Penerapan Strategi Pembelajaran Peningkatan Kemampuan Berpikir pada Mata Pelajaran Fiqih Materi Zakat di Madrasah Tsanawiyah Negeri Batusangkar Kabupaten Tanah Datar. In International Seminar on Education 2017 Empowering Local Wisdom on Education for Global Issue (pp. 35-44).

Kunandar. (2013). Penilaian Autentik. Jakarta: PT Raja Grafindo Persada.

Sanjaya, W. (2014). Strategi Pembelajaran. Jakarta: Kencana Prenada Media Group.

Toharuddin, U. (2011). Membangun Literasi Sains Peserta Didik. Jakarta: Bumi Aksara.

\section{Article Metadata:}

Widiana, R. Maharani, A.D. Rowdoh. (2020). The Effect of Problem-Based Learning Model on High School Students' Science Literacy. Ta'dib, 23 (1), 87-94.

http://dx.doi.org/10.31958/jt.v23i1.1689

Keywords: Problem Based Learning, Science Literacy

Coresponding author: Ade Dewi Maharani, STKIP PGRI Sumatera Barat, adedewimaharani@gmail.com 